\title{
SMEs Performance in Malaysia: The Role of Contextual Ambidexterity in Innovation Culture and Performance
}

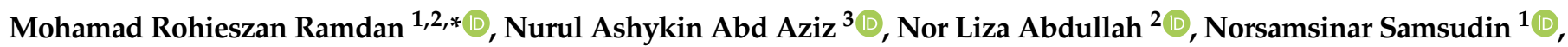 \\ Gurcharanjit Singh Veer Singh ${ }^{2}{ }^{\mathbb{D}}$, Thuraiya Zakaria ${ }^{1} \mathbb{D}$, Nursyazwani Mohd Fuzi ${ }^{4} \mathbb{D}$ and \\ Sharon Yong Yee Ong ${ }^{5}$
}

\section{check for}

updates

Citation: Ramdan, M.R.; Abd Aziz, N.A.; Abdullah, N.L.; Samsudin, N.; Singh, G.S.V.; Zakaria, T.; Fuzi, N.M.; Ong, S.Y.Y. SMEs Performance in Malaysia: The Role of Contextual Ambidexterity in Innovation Culture and Performance. Sustainability 2022, 14, 1679. https://doi.org/10.3390/ su14031679

Academic Editor: Daniel Arias Aranda

Received: 29 December 2021

Accepted: 28 January 2022

Published: 1 February 2022

Publisher's Note: MDPI stays neutral with regard to jurisdictional claims in published maps and institutional affiliations.

Copyright: (C) 2022 by the authors. Licensee MDPI, Basel, Switzerland. This article is an open access article distributed under the terms and conditions of the Creative Commons Attribution (CC BY) license (https:// creativecommons.org/licenses/by/ $4.0 /)$.
1 Faculty of Management and Economics, Universiti Pendidikan Sultan Idris, Tanjong Malim 35900, Perak, Malaysia; norsamsinar@fpe.upsi.edu.my (N.S.); thuraiya@fpe.upsi.edu.my (T.Z.)

2 Faculty of Economics and Management, Universiti Kebangsaan Malaysia, Bangi 43600, Selangor, Malaysia; iza@ukm.edu.my (N.L.A.); p102554@siswa.ukm.edu.my (G.S.V.S.)

3 Faculty of Entrepreneurship and Business, Universiti Malaysia Kelantan, Locked Bag 36, Pengkalan Chepa, Kota Bahru 16100, Kelantan, Malaysia; ashykin.a@umk.edu.my

4 Azman Hashim International Business School, Universiti Teknologi Malaysia, Johor Bahru 81310, Johor, Malaysia; nursyazwani.mohdfuzi@utm.my

5 Faculty of Humanities, Management and Science, Universiti Putra Malaysia Bintulu Campus, Bintulu 97008, Sarawak, Malaysia; sharon.ong@upm.edu.my

* Correspondence: rohieszan@fpe.upsi.edu.my

\begin{abstract}
Small and medium-sized enterprises (SMEs) in both the industrial and service sectors have been identified as the drivers of Malaysia's fast economic growth. However, SMEs are faced with an inherent issue of lack of resources and capabilities which constrains the ability of SMEs to improve performance. Due to this, it is critical for SMEs to understand and develop an important capability that supports them in facing a dynamic and competitive business environment. This study examines the mediating role of contextual ambidexterity as a dynamic capability in the relationship between innovation culture and SME performance. The online surveys were carried out starting from 5th July until 25th July 2021. A total of 277 SMEs in Selangor, Malaysia participated in this study and Covariance-Based Structural Equation modeling analysis was utilized to test the hypotheses. The findings show that in terms of direct relationships, innovation culture has a significant positive relationship with contextual ambidexterity, while innovation culture and contextual ambidexterity have a significant positive relationship with SME performance. The findings showed that contextual ambidexterity is significant as a mediator in the relationship between innovation culture and SME performance. This study makes an important contribution to the management field by highlighting the role of contextual ambidexterity, which is often the focus of large companies. These findings support the notion of dynamic capability that accentuates the importance of developing capabilities in dealing with dynamic and challenging situations.
\end{abstract}

Keywords: innovation culture; contextual ambidexterity; SMEs performance; Malaysia

\section{Introduction}

Small and medium enterprises (SMEs) in the manufacturing and services sectors play an important role in the economy and are acknowledged to be the backbone of economic development. This is because the main importance of entrepreneurship is to create job opportunities, enhance innovation, and improve the economy [1-3]. Emerging trends have seen a surge in the number of SMEs in Malaysia, which recorded an increase from 1,113,157 SMEs in 2016 to 1,151,339 SMEs in 2021 [4]. In line with this, SMEs in Malaysia contributed 38.2 percent of Gross Domestic Product (GDP) in 2021 [5], and accounted for 97.2 percent of total business growth in 2020, regardless of sector or size [4]. This sector provided employment opportunities for more than 48.0 percent of the total workforce 
in Malaysia in 2020 [5]. Meanwhile, the export contribution of SMEs in Malaysia to total exports in 2020 was 13.5 percent, of which 9.4 percent was from the manufacturing sector, 3.9 percent from the services sector, and 0.3 percent from the agriculture sector [5]. Currently, the agriculture sector has recorded growth due to the increase in SMEs exports of vegetables, fisheries, poultry, bananas, and durian. Malaysia is targeting China, Singapore, and Hong Kong as the main destinations for exports.

Despite the tremendous growth in terms of the numbers and contributions of SMEs to the Malaysian economy, recent issues such as the health crisis caused by the COVID-19 pandemic in 2020 [5] have impacted SMEs. More specifically, the performance of all sectors of the economy has declined with the implementation of the Movement Control Order (MCO) across the country, which includes numerous measures to combat the spread of COVID-19. This is reflected in the 7.3 percent reduction in SMEs GDP in 2020, which is larger than the 5.6 percent and 4.6 percent declines in Malaysia's GDP and Non-SMEs GDP, respectively [5]. Furthermore, Malaysian SMEs lack focus on innovation, and this has caused SMEs innovation success rates to fall short of the desired rate [6]. This is evidenced by the Global Innovation Index (GII) 2019, where Malaysia's position remains at the same level, ranked 35th in 2019, 32nd in 2015, and 33rd in 2014 [7]. This index clearly shows that the growth of innovation performance in Malaysia is very slow compared to Singapore (8th), South Korea (11th), Hong Kong (13th), and Japan (15th) in 2019. It clearly shows a prevalent issue in innovation and the lack of innovative acumen and capability among SMEs has mitigated the potential of SMEs in improving firm performance.

One of the reasons why most firms are unable to drive innovation is the difficulty of leaders adopting thoughtful ideas from others [8], whereas firm leaders must develop a longterm culture of innovation to succeed. Leaders need to develop sustainable innovation culture that supports cooperation and provides autonomy, support for research initiatives, trust, thoughtfulness, and acknowledgment to employees [9]. The innovation culture approach in addition to the combination of advanced technology utilized by organizations can have a higher impact on firm performance [10]. Clearly, having an innovation culture in place that is effectively supported by top management encourages new product development or more innovative services that will have a long-term positive impact on the firm performance.

Although innovation is acknowledged for long-term success, many managers of SMEs fail to bring new products or services to the market [11,12]. According to Lee, et al. [13], this problem stems from a lack of understanding related to management practices to lead innovation. Essentially, innovation culture encourages employees to be equally creative, risk-taking, and able to develop ideas and create new opportunities in organizations [14]. In fact, these features require both the implementation of exploration and exploitation because improvement activities, modification of existing systems, and current processes require new ideas to be more creative and innovative [15]. More clearly, contextual ambidexterity is an organizational learning activity that can help firms find solutions to the challenges they face while implementing an innovation culture [16]. This suggests that effective organizational learning is able to further maximize creativity and innovation through an innovation culture within their firms [17]. In addition, most of the studies that have been conducted related to innovation culture are more focused on large-sized firms and in developed countries [8]. Therefore, in the current situation, the culture of innovation is important to SMEs and developing countries in order to ensure the sustainability of this sector.

Based on the above discussion, this study was conducted to examine the direct relationship between innovation culture and SMEs performance in Malaysia and the indirect relationship between innovation culture and SMEs performance through contextual ambidexterity, which serves as a mediating variable. The remainder of this work is structured as follows. Section 2 provides a review of the literature review, theory, and proposed hypotheses. Section 3 presents the research methodology. Section 4 presents the results of the empirical findings of the study. Section 5 provides a discussion, theoretical implications, practical implications, limitations, and future research and conclusions. 


\section{Literature Review}

\subsection{Small and Medium Enterprises (SMEs) in Malaysia}

Small and Medium Enterprises (SMEs) in Malaysia are classified based on the number of employees and total annual sales generated in two industries: manufacturing and services. In this study, SMEs are defined as manufacturing firms with annual sales of less than RM 50 million and full-time employees of less than 200 people, and services firms with annual sales of less than RM 20 million and full-time employees of less than 75 people [18] (see Table 1).

Table 1. Definition of SMEs by category.

\begin{tabular}{ccccc}
\hline & \multicolumn{4}{c}{ Sector } \\
\cline { 2 - 5 } Manufacturing & \multicolumn{2}{c}{ Services and Other Sectors } \\
\cline { 2 - 5 } Classification & Annual Sales & $\begin{array}{c}\text { Number of } \\
\text { Employees }\end{array}$ & Annual Sales & $\begin{array}{c}\text { Number of } \\
\text { Employees }\end{array}$ \\
& RM 300,000 & $<5$ people & $<$ RM 300,000 & $<5$ people \\
Micro & RM 300,000 $<$ & From 5 to $<75$ & RM 300,000 $<$ & From 5 to $<30$ \\
Small & RM 15 million & people & RM 3 million & people \\
& RM 15 million $<$ & From 75 to $<200$ & RM 3 million $<$ & From 30 to $<75$ \\
Medium & RM 50 million & people & RM 20 million & people \\
\hline
\end{tabular}

Source: SME Corp. Malaysia [18].

\subsection{SMEs Performance}

Performance is the main goal of every SME firm to remain competitive in the business arena [19]. Performance is described as an entity, individual, group, or organization ability to achieve a certain goal through a series of activities [20]. Performance is also seen as the firm's ability to achieve goals through work behavior and achievement while performing tasks [21]. Specifically, firm performance can be measured from financial and non-financial perspectives. According to Chen, et al. [22], financial performance measurement is more obvious in demonstrating a competitive advantage than other performance measures. Conceptually, financial performance may be evaluated using either objective or subjective criteria, or both [23]. Nonetheless, past studies have discovered that most organizations are more inclined to provide subjective information related to their firm's performance. This is especially true in the case of small firms which are normally not able to systematically compile their financial data, making it difficult for them to provide objective facts in empirical form to external parties. As a result, they are inclined to give subjective indicators as the components are more flexible and at the same time do not explicitly expose information that is regarded as confidential to outsiders [24]. However, a comprehensive approach to understanding firm performance should involve both financial and non-financial performance. Many researchers (e.g, $[25,26])$ believe that non-financial performance factors are important drivers in financial decision-making. According to Tsou and Hsu [27], financial performance refers to a firm's ability to generate income from major sources of business, such as assets. Meanwhile, non-financial performance entails long-term goals that highlight the significance of building customer loyalty, attracting new consumers, and improving the firm's image and reputation $[27,28]$. To evaluate firm performance, this study defines SMEs performance as the firm's ability to achieve set objectives using a combination of financial and non-financial performance measurements [22,27,28].

\subsection{Innovation Culture}

According to Tushman and O'Reilly III [29], one of the variables regarded to be at the core of a firm's innovation capabilities is organizational culture. SMEs firms in particular are encouraged to innovate when organizational culture characteristics are embedded in the firm, thus becoming the pillar for the firm's capacity to innovate [30]. This implies that to stimulate innovation and have a greater impact on business performance, an innovation- 
oriented culture must be created [31]. To put it another way, SMEs must foster an innovation culture in order to have the most influence on firm performance [32]. The term "innovation" is commonly used to describe a company's proclivity to develop new processes, products, or ideas [33], and "culture" is described as a property of groups that is formed based on a pattern of basic assumptions from accumulated learning that a given group has acquired during its history [34]. A culture that is focused on innovation is related to features accepted and practiced in the organization that generates a firm's proclivity to innovation. Several words have been used to describe such culture, including innovation-oriented culture [35], innovation-supportive culture [36], innovative culture [37], pro-innovation culture [13], and a culture of innovation [12]. These terms have been used to describe the same concept and have been used interchangeably. Conceptually, innovation culture is a managerial action that encourages employees to be creative, dare to take risks, be able to develop ideas, and create new opportunities for new product innovation processes $[12,14,33]$. Lee, et al. [13] defined "pro-innovation culture" as the nature of a firm's openness to adapt, accept new ideas, and be able to implement new processes in the organization. Thus, the innovation culture used in this study is defined as the implementation of new strategies that can motivate employees to be more creative, dare to take risks, develop ideas, and create new opportunities to improve firm quality and productivity [12,14,38].

\subsection{Contextual Ambidexterity}

Past literature has intensified focus on the topic of ambidexterity, which is acknowledged as one of the ways for firms to compete in a dynamic environment. In strategic management, Duncan [39] has established the notion of ambidexterity by putting in place "dual structures" so that certain divisions focus on alignment while others focus on adaptation. However, Duncan [39] only used the word "ambidextrous organization" in the title of a book chapter, with no reference to "ambidextrous organization" or "ambidexterity" in the text. In particular, organizational ambidexterity is defined as the ability of an organization to respond efficiently and in parallel to meeting market demands while at the same time being able to adapt to changing environments [40]. Following that, the same notion was examined in terms of organizations' ability to do two distinct activities, namely exploration and exploitation [41], simultaneously. Exploration, in particular, focuses on a firm's ability to learn new knowledge, discover new capabilities, and investigate new opportunities to grow business activities, whereas exploitation refers to a firm's ability to use existing internal knowledge, implement existing capabilities, and make sound decisions to maximize profits from business activities [42,43]. However, balancing exploration and exploitation to generate new products or services in order to secure a firm's profitability and long-term survival is a demanding and challenging undertaking [44,45]. According to Simsek, et al. [46], it can only be balanced by a distinct method via structural or temporal mechanisms. Nonetheless, Gibson and Birkinshaw [47] contend that contextual processes in organizations may effectively balance exploration and exploitation. Specifically, structural or temporal ambidexterity is defined as the implementation of exploration competencies and exploitation competencies by two different units, while contextual ambidexterity refers to the simultaneous implementation of exploration competencies and exploitation competencies $[29,47]$. Although exploration and exploitation are two distinct tasks within a business unit, by agreeing that the same effort may be done concurrently through contextual ambidexterity, small enterprises can increase their performance [40]. Therefore, in this study, contextual ambidexterity is defined as the ability of a firm to implement exploratory competencies and exploitative competencies simultaneously in generating the values needed to achieve good performance in the long term $[48,49]$.

\subsection{Resource-Based Theory, Dynamic Capability Theory, and Organizational Learning Theory}

An innovation culture may be a resource that gives a competitive advantage and increases organizational efficiency, resulting in a high level of competitiveness for the firm. This is supported by Resource-Based Theory, which states that organizational culture is 
a significant resource as it is an internal resource that is valuable, rare, inimitable, and non-substitutable [50]. When discussing organizational culture, significant emphasis is placed on the culture that helps employees to be more sensitive, creative, and inventive when confronted with an ever-changing environment [37]. Hanifah, et al. [8] explained that innovation practices are not easily adopted in the absence of a culture that encourages organizations to innovate. The culture of innovation consists of organizational capacity and the ability to innovate where existing skills, knowledge, and capability are available [31]. This increases the need for a culture of innovation to be nurtured in the business operations of a firm and to continue to contribute to the viability of a business [51]. Therefore, innovation culture needs to be nurtured and embedded in the firm's business operations for the survival of a business.

However, the ever-changing business environment has led to the development of Dynamic Capabilities Theory from Resource-Based Theory [52,53]. Teece, et al. [53] explain that "dynamic capability" is the ability of a firm to integrate, build, and reorganize internal and external resource capabilities according to changes in the environment. Dynamic capabilities are defined as processes to integrate, reconfigure, gain, and release resources to adapt a firm's actions to market changes or change the market environment itself [54]. Resource-Based Theory is focused on the characteristics of resources in developing competitive advantages and is thus unable to explain how resources can become obsolete or diminish in terms of competitiveness, especially in the face of environmental change. The continuously changing market environment has resulted in the application of organizational ambidexterity receiving greater attention due to its potential to retain competitiveness [55]. According to Eisenhardt and Martin [54], dynamic capability is a key factor in shaping high competitiveness through opportunity, seizing opportunities, and reconfiguration, whereas contextual ambidexterity, which involves exploration and exploitation activities simultaneously, can help organizations whether environmental change [56].

Meanwhile, other researchers (e.g, [57,58]) have extended Dynamic Capability Theory by looking at this issue through the lens of Organizational Learning Theory. The concept of organizational learning is highlighted as a source of firms' dynamic capability (e.g., [59,60]). In other words, the development of a firm's dynamic capability needs to be supported by organizational learning, i.e., the process of the firm learning about something $[53,61]$. Organizational Learning Theory has been conceptualized as a process of enhancing action through better knowledge and understanding [62]. Key components in the organizational learning process include knowledge acquisition, information dissemination, information interpretation, and organizational memory [63]. According to Bates and Khasawneh [64], firms that can produce innovation via the application of organizational culture are the consequence of successful organizational learning. Indeed, Crossan, et al. [65], who developed a 4i framework of intuiting, interpreting, integrating, and institutionalizing to consolidate organizational learning and understanding in order to establish a clear relationship between strategy and learning, specifically addressed the tension between assimilating new learning (exploration) and applying what has been learned (exploitation). As a result, building a culture of creativity and implementing contextual ambidexterity through organizational learning is critical for achieving exceptional organizational performance.

\subsection{Innovation Culture and Contextual Ambidexterity}

Resource-Based Theory, which explains the importance of internal resources in improving organizational efficiency to achieve competitive advantage [50], stresses the importance of innovation culture as a resource that will lead to firm success in the long term [13]. Furthermore, with the help of organizational learning, creativity and innovation will be more successful via an innovation culture within the firm [17]. Thus, innovation must be instilled in order to motivate staff to continually add knowledge through learning, the adoption of new methods, structural and routine modifications, and the provision of improved added value to customers [66]. In other words, knowledge development through contextual ambidexterity necessitates the promotion of an innovation culture for enter- 
prises to bring more new goods to market [67]. This is supported by previous empirical studies, such as the findings of Lee, et al. [13] in the United States (USA) on 110 software companies, which found that new product development performance was high when firms effectively implemented pro-innovation culture supported by contextual ambidexterity. Meanwhile, Ikhsan, et al. [68] discovered that firm performance was excellent among 133 SMEs in Indonesia's culinary, fashion, photography, and handicraft industries due to the successful adoption of organizational culture while supporting the implementation of effective contextual ambidexterity. Although Ikhsan, et al. [68] combine innovation culture and bureaucracy culture in organizational culture aspects, innovation culture is a better indicator of improved work processes to support innovation activities, particularly in dynamic environments. Thus, the following hypothesis is proposed:

Hypothesis 1 (H1). There is a significant positive relationship between innovation culture and contextual ambidexterity.

\subsection{Innovation Culture and SMEs Performance}

According to Resource-Based Theory, internal resources need to be fully utilized because they form the strength of the firm and they are valuable assets for a firm [50,69]. According to Barney [70], the related elements of innovation applied to organizational culture become a unique internal resource for enhancing organizational competitiveness. Innovation culture plays an important role for firms in creating new ideas in the production of new products or innovative services [66]. According to Bates and Khasawneh [64], firms that develop innovation through the application of organizational culture are the consequence of organizational learning. In other words, effective organizational learning will transpire when an innovation culture exists within the firm and this will lead to the development of more creative and inventive goods to increase firm performance [71], particularly in a dynamic setting. This evidence can be clarified through past studies such as the study of Dabić, et al. [31] in Croatia on 253 SMEs in downstream industries, such as construction, manufacturing, transportation, communications, utilities, wholesale and retail trade, finance, insurance, and real estate, personal services, business services, healthcare, and education, which found firm performance is high due to more effective application of a culture of innovation. According to the findings of Malaysian research conducted by Hanifah, et al. [8] that studied 140 SMEs in the services and manufacturing industries, innovation performance was high due to the adoption of an innovation culture to develop new, more inventive items. Thus, the following hypothesis is proposed:

Hypothesis 2 (H2). There is a significant positive relationship between innovation culture and SMEs performance.

\subsection{Contextual Ambidexterity and SMEs Performance}

Organizational Learning Theory describes the process of developing dynamic capability through improved knowledge and understanding in which businesses learn about new things [72,73]. Thus, via successful organizational learning processes, a balance between exploratory competences and exploitative competences may be reached at the same time $[48,65]$. Indeed, organizational learning techniques may successfully assist organizations in becoming more imaginative, adaptive, and capable of improving firm performance directly [46]. Similarly, Wang and Rafiq [48] define contextual ambidexterity as a dynamic skill that involves abilities to explore new knowledge and exploit existing knowledge that helps firms to achieve good performance through the development of market-leading innovative products. This implies that contextual ambidexterity is vital in the development of new products or creative services that fulfill customer needs [74]. This is supported by previous empirical studies, such as the findings of a study conducted in China by Cao, et al. [75] on 122 high-tech industries such as automation, electronics, and telecommunications, which discovered that firm performance is high due to the effective 
implementation of contextual ambidexterity. Meanwhile, Wang and Rafiq [48] discovered in a study of 150 firms in the United Kingdom (UK) and 242 firms in China in high-tech industries that the ability to implement contextual ambidexterity through the process of effective learning results in high-quality new product innovation in both countries. Thus, the following hypothesis is proposed:

Hypothesis 3 (H3). There is a significant positive relationship between contextual ambidexterity and SMEs performance.

\subsection{Innovation Culture and SMEs Performance: Contextual Ambidexterity as a Mediator}

Greater firm performance may be attained through creativity and innovation in the development of new products or the provision of more innovative services [76]. This is critical for SMEs to stay competitive in today's fast-paced competitive environment [77]. Based on Resource-Based Theory, which focuses on firm competitiveness from the characteristics of internal resources that are hard to obtain, inimitable, and irreplaceable [50], innovation culture as a resource should also be used to improve firm performance. Innovation culture can generate hard-to-obtain value, is difficult to imitate, and cannot be easily replaced [78]. However, there are still SMEs that lack of understanding of management practices to spearhead innovation [13]. In essence, effective learning is present in organizations that successfully innovate via the adoption of an innovation culture [64]. In other words, organizational learning helps firms produce new products or more innovative services through the adoption of a culture of innovation [17] and ultimately be able to achieve higher performance than existing competitors.

To improve business performance, the adoption of an innovative culture must be evaluated via human capital [79]. This is because the applied innovation culture must be able to develop individual and organizational behaviors that allow employees to execute exploration and exploitation to increase the stock of knowledge and, as a result, produce new products or more innovative services [13]. In particular, an innovation culture measured by human capital and involving holistic employee participation will facilitate the development of new processes [80], such as simultaneous exploration and exploitation that combine external and internal knowledge to create new products or services [48]. More specifically, contextual ambidexterity is more successful when enterprises embrace an innovation culture that encourages employees to be more responsive to environmental changes as well as to be more creative and imaginative in mobilizing resources [13,37]. Despite this, Terziovski [12] discovered in a survey of 195 SMEs in the manufacturing industry in Australia that the performance of enterprises was low because they were unable to implement an innovation culture in a systematic and organized manner. Nonetheless, the findings of Jahan and Akbar [81] in a study of 414 high-tech businesses in India show that when contextual ambidexterity is implemented through innovation culture, the creation of new product innovation is high. Thus, this study proposes the following hypothesis:

Hypothesis 4 (H4). Contextual ambidexterity mediates the relationship between innovation culture and SMEs performance.

\section{Research Methodology}

\subsection{Sample and Procedures}

Data was collected using a survey approach from enterprising SMEs in the manufacturing and service sectors in Selangor, Malaysia. The state of Selangor was chosen because Selangor has the largest distribution of SMEs in Malaysia [82]. Moreover, these SMEs were chosen because they work in a competitive and dynamic environment in which the ability to innovate is critical for development and excellent performance [83]. Furthermore, by sampling SME in the manufacturing and services sector, this study focuses on small and medium enterprises that have been operating for more than three years, because the length of operations is an important indicator to measure a firm's stability in 
weathering the changing business environment. In fact, this is in line with previous studies that have used this criteria in organizational learning research, e.g., Lee, et al. [13] and Wang and Rafiq [48]. A purposive sampling technique was used to identify and access the respondents; 350 questionnaires were distributed to the CEOs of SMEs in the state of Selangor, as they are the people who understand the business culture, structure, and market circumstances [43]. A brief introduction to the study was given on the first page of the questionnaire. Respondents were promised that their replies would be kept strictly secret and that their data would only be used for academic purposes by the study team. Given the country's present condition due to the COVID-19 outbreak, the questionnaire was distributed using e-mail [84]. The respondents were given three weeks to complete the surveys starting from 5th July until 25th July 2021. Reminders were issued to responders using the organization's emailing system in the third week.

After three weeks, 300 participants returned the questionnaires, yielding a response rate of 86 percent. The preliminary analysis of data revealed 23 as outliers that were dropped from the dataset. The data met the multivariate assumptions of outlier, normality, linearity, homoscedasticity, and multicollinearity [85]. As a consequence, only 277 surveys were evaluated, which is sufficient sample size for the Covariance-Based Structural Equation Modeling (CB-SEM) analytic approach [86].

According to firm background investigations, the majority of enterprises (143 firms) were in the service sector, while the rest (134 firms) were in manufacturing and other sectors. The bulk of the enterprises (215 employers) employed 5 to 30 people, while 62 employers employed more than 30 workers. In terms of ownership, 140 firms were sole proprietors, followed by Sendirian Berhad corporations (83 firms), partnerships (45 firms), and limited liability partnerships (9 firms). Finally, most of the firms generated revenue of RM 300,000 to RM 3 million annually (217 firms), followed by RM 16 million to RM 20 million annually (28 firms), RM 4 million to RM 15 million annually (18 firms), and RM 21 million to RM 50 million annually (14 firms).

\subsection{Measures}

All constructs were evaluated using validated measures that had been used in previous studies. Innovation culture was assessed using six items from a study by Aksoy [14] which was adapted from a study by Terziovski [12] on innovation practice. Each item was scored on a five-point scale ranging from 1 (strongly disagree) to 5 (strongly agree). Next, contextual ambidexterity was measured using five questions for exploration competency and five items for exploitation competency from a study by Wang and Rafiq [48], which was derived from the Atuahene-Gima [49] study. Each item was graded on a seven-point scale ranging from 1 (very little knowledge) to 7 (very substantial knowledge). Finally, SMs performance was measured using five financial performance indicators and five nonfinancial performance indicators adopted from a study by Chen, et al. [22]. Furthermore, these measures have been extensively accepted in many studies, for example Tsou and $\mathrm{Hsu}$ [27]. Each item was scored on a five-point scale ranging from 1 (strongly disagree) to 5 (strongly agree).

Before conducting the main study, the questionnaire was pre-tested and piloted to establish content validity, face validity, and construct reliability. Following convention, the content validity of the instruments for the current study was determined by analyzing the literature linked to the study measures used in prior investigations [87]. Furthermore, a pre-test was undertaken with a small group of entrepreneurship and strategic management academics to see whether the scale items truly reflect the notions assessed. Based on the feedback, several elements were eliminated as they had the same meaning and were modified. As a result, content validity was assured. The early draft of the questionnaire was tested on a sample of respondents to determine face validity for this study by measuring their reaction to the items [87]. The questionnaire was then piloted on 30 respondents from SMEs in Wilayah Persekutuan Kuala Lumpur, Malaysia. The Cronbach's alpha for all variables varied from 0.759 to 0.85 according to the results of this pilot research. As a result, 
this reliability evaluation offered early evidence that the items assessing the variables for this study have internal consistency (see Table 2).

Table 2. Items to measure the study constructs.

\begin{tabular}{|c|c|c|}
\hline Constructs & Items & Cronbach's Alpha \\
\hline $\begin{array}{l}\text { Innovation } \\
\text { Culture (IC) }\end{array}$ & $\begin{array}{l}\text { IC1-Our organization's culture behaviors that relate to creativity and innovation. } \\
\text { IC2-Our organization's culture encourages informal meetings and interactions. } \\
\text { IC3-Our organization's culture encourages employees to monitor their own performance. } \\
\text { IC4-Employees take risks by continuously experimenting with new ways of doing things. } \\
\text { IC5-Our organization's culture encourages employees to share knowledge. } \\
\text { IC6-Our organization's culture focuses on long term performance teamwork. }\end{array}$ & 0.79 \\
\hline \multirow{5}{*}{$\begin{array}{c}\text { Contextual } \\
\text { Ambidexterity (CA) }\end{array}$} & Over the last three years, this firm has ... & \multirow{5}{*}{0.81} \\
\hline & exploration competency & \\
\hline & $\begin{array}{l}\text { CA1—acquired technologies and skills entirely new to the firm. } \\
\text { CA2-learned product development skills and processes entirely new to the industry. } \\
\text { CA3-acquired entirely new managerial and organizational skills that are important for innovation. } \\
\text { CA4- learned new skills for the first time. } \\
\text { CA5—-strengthened innovation skills in areas where it had no prior experience. }\end{array}$ & \\
\hline & exploitation competency & \\
\hline & $\begin{array}{l}\text { CA6-upgraded current knowledge and skills for familiar products and technologies. } \\
\text { CA7-enhanced skills in exploiting well-established technologies that improve productivity of } \\
\text { current innovation operations. } \\
\text { CA8-enhanced competences in searching for solutions to customer problems that are close to } \\
\text { established solutions rather than completely new solutions. } \\
\text { CA9-upgraded skills in product development processes in which the firm already possessed } \\
\text { significant experience. } \\
\text { CA10-strengthened the knowledge and skills for projects that improve efficiency of existing } \\
\text { innovation activities. }\end{array}$ & \\
\hline \multirow{5}{*}{$\begin{array}{c}\text { SMEs } \\
\text { performance } \\
(\mathrm{SMEP})\end{array}$} & Generally speaking, for the past few years ... & \multirow{5}{*}{0.85} \\
\hline & financial performance & \\
\hline & $\begin{array}{l}\text { SMEP1 — we have enhanced sales and profitability of the firm. } \\
\text { SMEP2 - we have achieved profit objectives. } \\
\text { SMEP3 - we have achieved sales objectives. } \\
\text { SMEP4 - we have achieved market share objectives. }\end{array}$ & \\
\hline & non-financial performance & \\
\hline & $\begin{array}{l}\text { SMEP5—-we have improved the loyalty of existing customers. } \\
\text { SMEP6-we have attracted a significant number of new customers. } \\
\text { SMEP7—we have had an important competitive advantage. } \\
\text { SMEP8—-we have had a well perceived image. } \\
\text { SMEP9—-we have had a good reputation. }\end{array}$ & \\
\hline
\end{tabular}

\subsection{Common Method Bias}

This study used a three-stage approach to adjust for potential common method bias that emerged from using self-reported data from single informants because of their tendency for overvaluation $[88,89]$. First, adapting measurement items from various sources ensures respondents' confidentiality, stresses no right or incorrect responses, and refines the measurement items. Second, data were gathered from the CEOs of SMEs, who were familiar with and understood their company's strategy, performance, and market characteristics. Finally, the Harman single-factor test was performed, with all variables included in the exploratory factor analysis [90]. According to the results, the first factor explained $48 \%$ of the variance. This variation was less than $50 \%$, indicating that common method bias was unlikely to be an issue $[89,91]$.

\section{Empirical Study}

The study assumptions were examined using a Covariance-Based Structural Equation Model (CB-SEM). CB-SEM was chosen over other analytical techniques because of its suitability for testing comprehensive and complex models. Specifically, CB-SEM can evaluate direct and indirect relationships as a whole, including estimates of sample parameters to be 
tested simultaneously, can minimize measurement error with confirmatory factor analysis (CFA), and can provide better model visualization [92]. As Anderson and Gerbing [93] suggested, this study assessed the conceptual model in two parts. First, confirmatory factor analysis (CFA) was used to verify the measurement model's construct validity; second, CB-SEM analysis was used to conduct a structured model assessment to test the suggested hypotheses.

\subsection{Confirmatory Factor Analysis (CFA)}

CFA was used to validate factor structure and demonstrate convergent and discriminant validity. The goodness-of-fit statistics for the measurement model suggested that the model fit was adequate. The Maximum Likelihood method [94] was used to estimate the parameters. To assess goodness-of-fit for measurement and structural models, the chi-square $\left(\chi^{2}\right)$, Root Mean Square Error of Approximation (RMSEA), Standardized Root Mean Residual (SRMR), Comparative Fit Index (CFI), Tucker-Lewis Index (TLI), and normed Chi-square were utilized. Initially, the overall goodness-of-fit suggested that the measurement model was not acceptable. The model was modified in three steps: validating standardized path estimates, standardized residual covariance matrix, and modification indices [92,95]. The examination results showed standardized path estimates for no items below the value of 0.5 [86], while the standardized residual covariance matrix showed that items CI4 and CI6 exceeded the value of \pm 4 [95], while modification indices revealed CA8, SMEP3, SMEP4, SMEP5, and SMEP7 had extremely high values, requiring items to be removed from the study data. There were four remaining innovation culture components, nine for contextual ambidexterity, five for SME performance, and eighteen for the overall number of items employed. The goodness-of-fit value achieves the acceptance stage after item issuance, and the model is suitable for the structured assessment model. As shown in Table 3, the measurement methodology is suitable for measuring construct validity and reliability.

Table 3. Measurement model.

\begin{tabular}{ccccccc}
\hline Goodness-of-Fit & $\chi^{2}(\mathbf{d f}, \boldsymbol{p})$ & $\chi^{2} / \mathbf{d f}$ & CFI & TLI & RMSEA & SRMR \\
\hline Measurement model & $\begin{array}{c}1228.154 \\
(482,0.000)\end{array}$ & 2.548 & 0.91 & 0.90 & 0.07 & 0.04 \\
Acceptable value * & $\begin{array}{c}\text { Significant } \\
\text { on } \alpha=0.05\end{array}$ & $1.0-5.0$ & $>0.9$ & $>0.9$ & $<0.08$ & $<0.08$ \\
\hline * & & &
\end{tabular}

* Note: Adapted with permission from ref: Hair, et al. [86] determined the level of acceptability.

Next, confirmation of convergent validity, reliability, construct reliability (CR), and average variance extracted (AVE) were examined [86]. According to Table 3, $\alpha$ value is (0.72-0.88), CR ranges from 0.86 to 0.95 , and AVE ranges from 0.60 to 0.68 . As a consequence, the results confirm the construct's reliability [86], indicating internal consistency.

The AVE, standardized factor loadings, and CR were used to assess convergent validity. Table 3 shows that each construct's AVE and CR values are greater than 0.5 and 0.7 , and that all items' standardized factor loadings are significant and greater than 0.7 . This signifies convergent validity, that the items used to assess the assigned concept positively correlate with one another.

Lastly, the discriminant validity of the AVE was then assessed by comparing the square root of the AVE to the relevant inter-construct correlations (IC) [96]. The square root of the AVE for each concept is greater than the inter-construct correlations (IC), suggesting that the items have more in common with their particular concept than with other constructs, according to the findings (see Table 4). 
Table 4. Evaluation of the Measurement Model.

\begin{tabular}{|c|c|c|c|c|c|}
\hline \multirow{2}{*}{ Measure } & \multicolumn{3}{|c|}{ Inter-Construct Correlations (IC) } & \multirow{2}{*}{ AVE } & \multirow{2}{*}{ CR } \\
\hline & IC & CA & SMEP & & \\
\hline $\begin{array}{c}\text { Innovation Culture (IC) }^{\text {Inno-8 }} \\
(0.820-\mathrm{IC} 1,0.840-\mathrm{IC} 2,0.720-\mathrm{IC} 3,0.730-\mathrm{IC} 5)^{\mathrm{a}}\end{array}$ & $0.78^{b}$ & & & 0.61 & 0.86 \\
\hline $\begin{array}{c}\text { Contextual Ambidexterity (CA) } \\
\text { (0.796-CA1, 0.837-CA2, 0.822-CA3, } \\
0.742-C A 4,0.820-C A 5,0.882-C A 6, \\
0.874-C A 7,0.848-C A 9,0.836-C A 10)^{a}\end{array}$ & 0.69 & $0.83^{b}$ & & 0.68 & 0.95 \\
\hline $\begin{array}{c}\text { SMEs Performance (SMEP) } \\
\text { (0.829-SMEP1, 0.794-SMEP2, 0.753-SMEP6, } \\
\text { 0.741-SMEP8, 0.778-SMEP-9) a }\end{array}$ & 0.54 & 0.79 & $0.78^{b}$ & 0.60 & 0.88 \\
\hline
\end{tabular}

Note: AVE $=$ average variance extracted $=\sum$ squared loadings $/ \mathrm{n}, \mathrm{CR}=$ construct reliability $=\left(\sum \text { loading }\right)^{2} /[(\Sigma$ loading $)^{2}+\sum$ (1-factor loading $\left.{ }^{2}\right]{ }^{,}$a standardized factor loadings, all significant at $p<0.001,{ }^{\text {b }}$ square root of AVE (diagonal elements in bold).

\subsection{Main Results}

In keeping with the proposed conceptual model to test the hypotheses, a structural model was developed $\left(\chi^{2}=798.412, \mathrm{df}=291, p=0.000\right)$ is significant, $\chi^{2} / \mathrm{df}=2.744$ is below $5, \mathrm{CFI}=0.92$ and TLI $=0.91$ and thus are above 0.9 , and $\mathrm{RMSEA}=0.07$ and SRMR $=0.04$ and thus are lower than 0.08 ). Hence, the overall model fit is adequate to test the proposed hypotheses. Furthermore, the value of $\mathrm{R}^{2}$ indicates that 66.0 per cent of the total variation in contextual ambidexterity can be explained by the innovation culture. In particular, the relationship between innovation culture and contextual ambidexterity shows a significant positive relationship ( $\beta=0.49, p<0.001$ ). Meanwhile, the value of $\mathrm{R}^{2}$ indicates that 82.0 per cent of the variation that exists in SMEs performance can be explained by both variables, namely innovation culture and contextual ambidexterity. Specifically, the relationship between innovation culture and SMEs performance was significantly positive $(\beta=0.62$, $p<0.001$ ), while contextual ambidexterity and SMEs performance had a significant positive relationship $(\beta=0.35, p<0.001)$. This proves that $\mathrm{H} 1, \mathrm{H} 2$ and $\mathrm{H} 3$ are supported. In summary, the results of the study indicate that the implementation of a higher innovation culture tends to contribute to a higher level of contextual ambidexterity. The overall test results on the direct relationship of the structural model and hypotheses are presented in Table 5.

Table 5. Summary of the Hypotheses Testing Related to Direct Effects.

\begin{tabular}{|c|c|c|c|c|}
\hline Hypothesized Path & Expected Direction & Standardized Estimate & $t$-Value & Result \\
\hline \multicolumn{5}{|l|}{$R^{2}(C A)=0.66$} \\
\hline $\mathrm{H}_{1}: \mathrm{CI} \rightarrow \mathrm{CA}$ & + & $0.49^{* * *}$ & 8.70 & Supported \\
\hline \multicolumn{5}{|l|}{$R^{2}(S M E P)=0.82$} \\
\hline $\mathrm{H}_{2}: \mathrm{CI} \rightarrow \mathrm{SMEP}$ & + & $0.62 * * *$ & 8.91 & Supported \\
\hline $\mathrm{H}_{3}: \mathrm{CA} \rightarrow \mathrm{SMEP}$ & + & $0.35^{* * *}$ & 5.73 & Supported \\
\hline \multicolumn{5}{|c|}{$\begin{array}{c}\text { Goodness-of-fit statistics: } \chi^{2}=798.412(\mathrm{df}=291, p=0.000), \chi^{2} / \mathrm{df}=2.744, \mathrm{CFI}=0.92, \mathrm{TLI}=0.91, \\
\mathrm{RMSE}=0.07, \mathrm{SRMR}=0.04\end{array}$} \\
\hline
\end{tabular}

Next, evaluation of the mediation relationship was performed through CB-SEM with bootstrapping method. The multiplication method by producing 1000 multiple samples to perform an indirect relationship at the confidence level of 95 per cent was used to analyze the mediation relationship in AMOS [97]. The direct model was used to examine the direct relationship between innovation culture and SMEs performance to confirm a significant relationship. The direct and indirect links of innovation culture on SMEs performance were evaluated in the mediation model after it was confirmed, proving the presence of contextual ambidexterity as a mediating variable. 
The findings show that a significant direct relationship exists between innovation culture and SMEs performance. On another note, contextual ambidexterity mediates the relationship between innovation culture and SMEs performance. Specifically, the results of the analysis for the direct relationship of an innovation culture and SMEs performance were significant $(\beta=0.62, p<0.01)$, and the indirect relationship through contextual ambidexterity was significant as well $(\beta=0.16, p<0.01)$ (see Table 6$)$. Accordingly, significant direct and indirect relationships indicate that contextual ambidexterity is able to act as a mediator in the relationship between innovation culture and SMEs performance. Therefore, H4 in this study is supported. The overall conceptual model of the role of contextual ambidexterity as a mediator in the relationship of innovation culture and SMEs performance is illustrated in Figure 1.

Table 6. Results of bootstrapping analysis for contextual ambidexterity as a mediator in the relationship between innovation culture and SMEs performance.

\begin{tabular}{|c|c|c|c|c|c|c|}
\hline \multirow{2}{*}{ Hypothesis Path Model } & \multirow{2}{*}{ Beta } & \multirow{2}{*}{$p$-Value } & \multirow{2}{*}{ Significant } & \multicolumn{3}{|c|}{ BC $95 \%$ CI } \\
\hline & & & & Lower Bound & Upper Bound & $\mathbf{0}$ \\
\hline \multicolumn{7}{|c|}{ Direct Model } \\
\hline $\mathrm{CI} \rightarrow \mathrm{SMEP}$ & 0.79 & $0.000 *$ & Yes & & & \\
\hline & & & Mediation Model & & & \\
\hline $\mathrm{CI} \rightarrow \mathrm{SMEP}$ & 0.62 & $0.003^{* *}$ & Yes & & & \\
\hline $\mathrm{CI} \rightarrow \mathrm{CA} \rightarrow \mathrm{SMEP}^{\mathrm{a}}$ & 0.16 & $0.006^{* *}$ & Yes & 0.05 & 0.25 & Outside \\
\hline Results & \multicolumn{6}{|c|}{ Mediation testing is accepted } \\
\hline
\end{tabular}

Goodness-of-fit statistics: $\chi^{2}=798.246(\mathrm{df}=290, p=0.000), \chi^{2} / \mathrm{df}=2.753, \mathrm{CFI}=0.92, \mathrm{TLI}=0.91, \mathrm{RMSEA}=0.08, \mathrm{SRMR}=0.04$

Note: CI-Innovation Culture, CA-Contextual Ambidexterity, SMEP-SMEs Performance. ${ }^{\text {a }}$ (indirect relationship), ${ }^{*} p<0.05(t>1.64),{ }^{* *} p<0.01(t>2.326)$
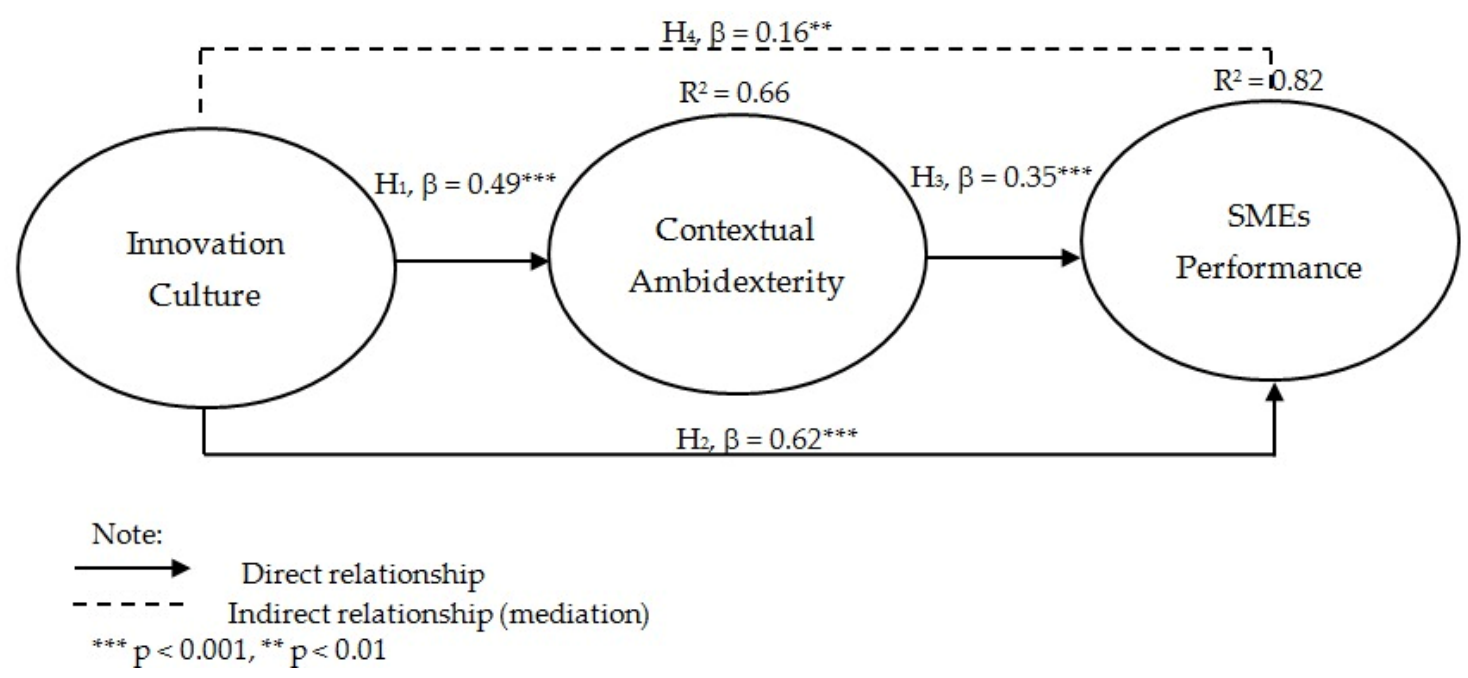

Figure 1. Conceptual model of the role of contextual ambidexterity as a mediator in the relationship between innovation culture and SMEs performance.

\section{Discussion}

This study investigates the relationship between innovation culture and SMEs performance in Malaysia and the role of contextual ambidexterity as a mediator in the relationship between the two constructs. CB-SEM analysis was used to examine data from a sample of 300 SMEs in Selangor, Malaysia. Before analyzing the main findings of the study, this study validates the factor structure for the measurement of innovation culture, contextual ambidexterity, and SMEs performance through CFA in order to ensure a quality measurement model and conformity. Furthermore, the study's main findings indicate a significant 
positive relationship for the direct relationship between innovation culture and SMEs performance and the indirect relationship between innovation culture and SMEs performance via contextual ambidexterity as a mediating variable. An explanation of this discussion is described below.

First, the results of the CFA test revealed that there were eighteen items with quality measures and conformity. Specifically, twenty-five items were originally chosen based on prior research, while only eighteen items were employed following the CFA test. This was due to measurement errors in the measurement model for two innovation culture items (CI4 and CI6), one contextual ambidexterity item (CA8), and four SMEs performance items (SMEP3, SMEP4, SMEP5, and SMEP7). Other items had acceptable measurements. Specifically, standardized factor loadings showed that the items for innovation culture ranged from 0.720 to 0.840 , contextual ambidexterity ranged from 0.742 to 0.882 , and SMEs performance ranged from 0.741 to 0.829 , higher than 0.5 [86]. This shows that the matching of the measurement models produced an adequate model. Thus, the measurements for the remaining items of innovation culture (four items), contextual ambidexterity (nine items), and SMEs performance (five items) were appropriate to the study context of examining the relationship between innovation culture and SMEs performance and testing the role of contextual ambidexterity as a mediator in both constructs in the context of a developing country such as Malaysia.

Second, the significant positive relationship between innovation culture and contextual ambidexterity is consistent with Resource-Based Theory, which states that organizational culture is a significant resource because it is an internal resource that is valuable, rare, inimitable, and non-substitutable. Clearly, in the discussion of organizational culture, much focus is given to the innovation culture that encourages employees to be more sensitive, creative, and innovative when faced with the ever-changing environment [37]. These findings are in line with other findings $[13,68]$ that examine the relationship between organizational culture or pro-innovation culture and contextual ambidexterity. In line with this, firms are encouraged to constantly produce more creative and innovative products in the market when innovative culture is instilled within the organization [17]. This suggests that innovative culture drives firms to constantly acquire new knowledge through exploration and exploitation [66]. Thus, the development of knowledge requires contextual ambidexterity so that firms are able to produce better quality products or services for customers [98].

Third, this study shows a significant positive relationship between innovation culture and SMEs performance. This is consistent with previous studies by Dabić, et al. [31] and Hanifah, et al. [8], who discovered that organizations that embrace an innovation culture produce excellent firm performance. Furthermore, firms that develop innovation via the implementation of an innovation culture are the result of organizational learning [64]. This study discovered a substantial positive relationship between contextual ambidexterity and SMEs performance. These findings are in line with previous studies that found that when firms successfully implement contextual ambidexterity, they are able to achieve superior firm performance [48]. This is clear because many studies find that contextual ambidexterity elements are capable of developing new items or unique services that will satisfy customers [74]. The importance of innovation is vital to SMEs since it is a fundamental aim of any organization to remain competitive in the business world [19].

Finally, significant findings on the indirect relationship between innovation culture and SMEs performance through contextual ambidexterity are consistent with the findings of previous studies [81]. This study supports Resource-Based Theory by demonstrating that innovation culture has a positive relationship with SMEs performance and contextual ambidexterity. In other words, Resource-Based Theory necessitates organizational learning support to encourage employees to be more sensitive to environmental changes as well as more creative and imaginative in assisting organizations in achieving superior performance. This study's findings show that the four hypotheses are validated and provide a better understanding of firm performance in a dynamic environment. In particular, innovation 
culture has a direct impact on SMEs performance. When contextual ambidexterity is included in the structural model, it acts as a mediator in the relationship between innovation culture and SMEs performance. These findings support the findings of Škerlavaj, et al. [37], who found that mediating factors are required in the relationship between innovation culture and SMEs performance.

Overall, the findings of this empirical study add to a better understanding of the importance of innovation culture in helping SMEs improve their performance, as SMEs must struggle to preserve their competitiveness in a dynamic environment. SME managers must strive to develop an innovation culture in order to generate more effective knowledge in the production of new products or services that are more innovative. This highlights the importance of contextual ambidexterity, which necessitates the promotion of an innovation culture that can help SMEs achieve greater performance, especially in a fast-changing environment. Following that, this study has some significant implications for the theoretical and practical SMEs in developing countries such as Malaysia, which will be discussed below.

\subsection{Theoretical Implications}

Theoretically, this study adds to the literature on strategic management and entrepreneurship by investigating the factors that influence SMEs performance in a dynamic environment. SMEs are often faced with the issue of lacking resources and capabilities such as finance, technology, and skilled labor, which become a constraint towards the improvement of firm performance. However, these problems must be addressed in order for businesses to attain success and continue to exist in the long run. Thus, this study fills gaps in the literature by correlating innovation culture with SMEs performance, which is critical for small and medium-sized enterprises. The study framework that includes the role of contextual ambidexterity can thoroughly explain the relationship between innovation culture and SMEs performance, which shows the importance to SMEs of further strengthening their knowledge.

In addition, this study combines the three theories involved, namely Resource-Based Theory, Dynamic Capability Theory, and Organizational Learning Theory, to give a more thorough explanation of how corporations operate in enhancing the performance of SMEs. The dynamic business environment pushes firms to adopt an innovation culture in order to be more creative and innovative in their product or service development [37]. However, SMEs that frequently face resource and capability constraints [99] require contextual ambidexterity as a dynamic capability capable of boosting firm knowledge through simultaneous exploration and exploitation [56]. This knowledge is mostly obtained through good organizational learning outcomes that build a clear link between strategy and learning [65]. The combination of these theories has proven the stated link between the components underpinning the theory based on the arguments presented.

\subsection{Practical Implications}

In practice, this study adds value to the management of SMEs, particularly in terms of propagating the importance of an innovation culture inside the firm. The findings indicate that when SMEs are aware of the relevance of innovation culture in the innovation process while capitalizing on contextual ambidexterity, their innovation performance and behavior will improve. In other words, fostering an innovation culture may elevate the production of new ideas and encourage more creative and inventive behavior among organization members. Similarly, organizations that have good leaders will successfully inculcate a culture, allowing the establishment of an inventive learning environment that supports risk-taking behavior in inventing and creating new products and services. This clearly demonstrates that innovation culture is extremely beneficial to SMEs, as it allows a firm's commercial operations to function creatively and efficiently and to achieve greater performance. Therefore, these findings emphasize to managers of SMEs in developing countries such as Malaysia the need to create an effective adoption of an innovation culture in order to improve the performance of their firms. 


\subsection{Limitations and Future Research}

There are several limitations of this study that need to be taken into account in understanding the findings of this study. This study uses non-probability sampling due to the unavailability of SMEs data in Selangor as required by the main criteria, namely, SMEs that have been in operation for at least three years. Due to this, the generalization of the study results is limited and can only be used to represent the research study population in Selangor, Malaysia. However, a study that involves a more comprehensive sample size and covers SMEs throughout Malaysia could expand the conclusions of the study findings. The study was done in a cross-sectional manner, in which data were collected only once, to provide a current picture of the phenomena surrounding innovation culture and SMEs performance. To understand the relationship in greater depth, a longitudinal method for collecting data over a period of time can explicate the causal effect clearly compared to a cross-sectional approach. Qualitative methodologies may be used to delve further into issues linked to SME performance. This study can be supported by qualitatively-shaped future studies and longitudinal sections in order to explore the contextual aspects of ambidexterity among SMEs. To acquire a more complete view of the link between innovation culture and contextual ambidexterity, future studies may take into account the way in which additional aspects such as digital platform capability, entrepreneurial orientation, and absorptive capacity are connected to the success of SMEs. Finally, CEOs that are capable of fostering culture and ambidexterity can have an impact on firm performance. Therefore, CEO characteristics should be researched in the future.

\subsection{Conclusions}

Overall, innovation culture was used in this study to determine its impact on the performance of SMEs. The success of SMEs is vital, as they contribute significantly to Malaysia's GDP. The findings indicate a beneficial correlation between innovation culture and the performance of SMEs. This study has demonstrated that when organizations are able to effectively construct an innovation culture, they are able to achieve higher performance. Furthermore, innovation culture has a positive effect on contextual ambidexterity, which has a positive impact on the SMEs performance. This demonstrates that contextual ambidexterity is a unique resource that can be used to maximize creativity and innovation in an organization by fostering an innovative culture. As a result, building a culture of innovation and capitalizing on contextual ambidexterity may lead to success in enhancing SMEs performance, and SMEs can then drive innovation to achieve business sustainability.

Author Contributions: M.R.R. focused on writing—original draft preparation, N.A.A.A. prepared conceptualization and resources, N.L.A. supervision, N.S. writing-review and editing, G.S.V.S. conducted validation, T.Z. managed project administration, N.M.F. methodology, S.Y.Y.O. formal analysis. All authors have read and agreed to the published version of the manuscript.

Funding: This research received no external funding.

Institutional Review Board Statement: Not applicable.

Informed Consent Statement: Not applicable.

Data Availability Statement: Not applicable.

Acknowledgments: Many thanks to all the contributions and support given by the authors in preparing the writing of this article.

Conflicts of Interest: The authors declare no conflict of interest.

\section{References}

1. Abd Aziz, N.A.; Ramdan, M.R.; Nik Hussin, N.S.; Abdul Aziz, Z.; Osman, J.; Hasbollah, H.R. The Determinants of Global Expansion: A Study on Food and Beverage Franchisors in Malaysia. Sustainability 2021, 13, 10328. [CrossRef]

2. Abd Aziz, N.A.; Hanafiah, M.H.; Abd Hamid, H.; Isa, R.M. Survival of Franchising Firm: A Study of Self-Service Laundry Franchisor. Int. J. Entr. 2019, 23, 1-6. 
3. Abd Aziz, N.A.; Hanafiah, M.H.; Hussin, N.S.N.; Abd Latif, M.N.; Aziz, Z.A. Franchising Relationship: Malaysian Franchisees' Perspectives. In The Importance of New Technologies and Entrepreneurship in Business Development: In the Context of Economic Diversity in Developing Countries; Springer International Publishing: Cham, Switzerland, 2021; pp. 317-335.

4. Department of Statistics Malaysia. Interactive Malaysia Statistical Business Register (i-MSBR); Department of Statistics Malaysia: Putrajaya, Wilayah Persekutuan Putrajaya, Malaysia, 2020.

5. Department of Statistics Malaysia. Performance of Small and Medium Enterprises (SMEs) 2020; Department of Statistics Malaysia: Putrajaya, Wilayah Persekutuan Putrajaya, Malaysia, 2021.

6. Abdul Halim, H.; Ahmad, N.H.; Geare, A.; Thurasamy, R. Innovation culture in SMEs: The importance of organizational culture, organizational learning and market orientation. Entrep. Res. J. 2018, 9, 1-14. [CrossRef]

7. Malaysia Science and Technology Information Centre (MASTIC). Position of Malaysia and Selected Countries Based on the Global Innovation Index (GII), 2013-2019; Ministry of Science, Technology and Innovation (MOSTI): Geneva, Switzerland, 2019.

8. Hanifah, H.; Halim, H.A.; Ahmad, N.H.; Vafaei-Zadeh, A. Can internal factors improve innovation performance via innovation culture in SMEs? Bench. Int. J. 2019, 27, 382-405. [CrossRef]

9. Kaasa, A. Culture as a possible factor of innovation: Evidence from the European Union and neighboring countries. In Re-Thinking Diversity; Bradel-Kuhner, C., Muller, A.P., Eds.; Springer VS: Wiesbaden, Germany, 2016; pp. 83-107.

10. Camisón, C.; Villar-López, A. Organizational innovation as an enabler of technological innovation capabilities and firm performance. J. Buss. Res. 2014, 67, 2891-2902. [CrossRef]

11. Dogbe, C.S.K.; Tian, H.-Y.; Pomegbe, W.W.K.; Sarsah, S.A.; Otoo, C.O.A. Market orientation and new product superiority among small and medium-sized enterprises (SMEs): The moderating role of innovation capability. Int. J. Innov. Manag. 2019, $24,2050043$. [CrossRef]

12. Terziovski, M. Innovation practice and its performance implications in small and medium enterprises (SMEs) in the manufacturing sector: A resource-based view. Stra. Manag. J. 2010, 31, 892-902. [CrossRef]

13. Lee, K.; Woo, H.-G.; Joshi, K. Pro-innovation culture, ambidexterity and new product development performance: Polynomial regression and response surface analysis. Eur. Manag. J. 2016, 35, 249-260. [CrossRef]

14. Aksoy, H. How do innovation culture, marketing innovation and product innovation affect the market performance of small and medium-sized enterprises (SMEs). Technol. Soc. 2017, 51, 133-141. [CrossRef]

15. Tian, H.; Dogbe, C.S.K.; Pomegbe, W.W.K.; Sarsah, S.A.; Otoo, C.O.A. Organizational learning ambidexterity and openness, as determinants of SMEs' innovation performance. Eur. J. Innov. Manag. 2020, 24, 414-438. [CrossRef]

16. Haghighi, M.; Dehghani Soltani, M.; Farsizadeh, H. Explaining the role of organizational ambidexterity in the Impact of pro-innovation culture and organizational memory on new product development performance. Manag. Res. 2018, 10, 197-223.

17. van Breda-Verduijn, H.; Heijboer, M. Learning culture, continuous learning, organizational learning anthropologist. Ind. Commer. Train. 2016, 48, 123-128. [CrossRef]

18. SME Corp. Malaysia Definition of SMEs. Available online: https://www.smecorp.gov.my/index.php/my/polisi/2020-02-11-0801-24/sme-definition (accessed on 2 December 2021).

19. Efrat, K.; Hughes, P.; Nemkova, E.; Souchon, A.L.; Sy-Changco, J. Leveraging of Dynamic export capabilities for competitive advantage and performance consequences: Evidence from China. J. Bus. Res. 2018, 84, 114-124. [CrossRef]

20. Laitinen, E.K. A dynamic performance measurement system: Evidence from small Finnish technology companies. Scan. J. Manag. 2002, 18, 65-99. [CrossRef]

21. Machmud, S.; Sidharta, I. Entrepreneurial motivation and business performance of SMEs in the SUCI Clothing Center, Bandung, Indonesia. DLSU Bus. Econ. Rev. 2016, 25, 63-78.

22. Chen, J.-S.; Tsou, H.T.; Huang, A.Y.-H. Service delivery innovation: Antecedents and impact on firm performance. J. Serv. Res. 2009, 12, 36-55. [CrossRef]

23. Sarkees, M.; Hulland, J.; Prescott, J. Ambidextrous organizations and firm performance: The role of marketing function implementation. J. Strateg. Mark. 2010, 18, 165-184. [CrossRef]

24. Cho, Y.H.; Lee, J.-H. Entrepreneurial orientation, entrepreneurial education and performance. Asia Pac. J. Innov. Entrep. 2018, 12, 124-134. [CrossRef]

25. Houck, M.; Speaker, P.J.; Fleming, A.S.; Riley, R.A., Jr. The balanced scorecard: Sustainable performance assessment for forensic laboratories. Sci. Justice 2012, 52, 209-216. [CrossRef] [PubMed]

26. de Waal, A.; Kourtit, K. Performance measurement and management in practice. Int. J. Prod. Perfor. Manag. 2013, 62, 446-473. [CrossRef]

27. Tsou, H.-T.; Hsu, S.H.-Y. Performance effects of technology-organization-environment openness, service co-production, and digital-resource readiness: The case of the IT industry. Int. J. Inf. Manag. 2015, 35, 1-14. [CrossRef]

28. Blazevic, V.; Lievens, A. Learning during the new financial service innovation process: Antecedents and performance effects. J. Bus. Res. 2004, 57, 374-391. [CrossRef]

29. Tushman, M.L.; O’Reilly III, C.A. Ambidextrous organizations: Managing evolutionary and revolutionary change. Calif. Manag. Rev. 1996, 38, 8-30. [CrossRef]

30. Wu, L.-F.; Huang, I.-C.; Huang, W.-C.; Du, P.-L. Aligning organizational culture and operations strategy to improve innovation outcomes: An integrated perspective in organizational management. J. Organ. Change Manag. 2019, 32, 224-250. [CrossRef]

31. Dabić, M.; Lažnjak, J.; Smallbone, D.; Švarc, J. Intellectual capital, organisational climate, innovation culture, and SME performance: Evidence from Croatia. J. Small Bus. Enterp. Dev. 2018, 26, 522-544. [CrossRef] 
32. Tang, G.; Park, K.; Agarwal, A.; Liu, F. Impact of innovation culture, organization size and technological capability on the performance of SMEs: The case of China. Sustainability 2020, 12, 1355. [CrossRef]

33. Salman, R.; Arshad, D.; Bakar, L.; Shabbir, M. The effect of innovative cultural processes on performance of small and medium size enterprises. Manag. Sci. Lett. 2018, 8, 1039-1048. [CrossRef]

34. Schein, E.H. Defining organizational culture. Class. Organ. Theory 1985, 3, 490-502.

35. Wynen, J.; Verhoest, K.; Ongaro, E.; Van Thiel, S.; Cooperation with the COBRA Network. Innovation-oriented culture in the public sector: Do managerial autonomy and result control lead to innovation? Pub. Manag. Rev. 2014, 16, 45-66. [CrossRef]

36. Chandler, G.N.; Keller, C.; Lyon, D.W. Unraveling the determinants and consequences of an innovation-supportive organizational culture. Entrep. Theory Pract. 2000, 25, 59-76. [CrossRef]

37. Škerlavaj, M.; Song, J.H.; Lee, Y. Organizational learning culture, innovative culture and innovations in South Korean firms. Expert Syst. Appl. 2010, 37, 6390-6403. [CrossRef]

38. Wallach, E.J. Individuals and organizations: The cultural match. Train. Dev. J. 1983, 37, 29-36.

39. Duncan, R.B. The ambidextrous organization: Designing dual structures for innovation. Manag. Org. 1976, 1, 167-188.

40. Birkinshaw, J.; Gibson, C.B. Building an ambidextrous organisation. Adv. Inst. Manag. Res. 2004, 45, 47-55. [CrossRef]

41. Rosing, K.; Zacher, H. Individual ambidexterity: The duality of exploration and exploitation and its relationship with innovative performance. Eur. J. Work Org. Psychol. 2017, 26, 694-709. [CrossRef]

42. O'Reilly III, C.A.; Tushman, M.L. Ambidexterity as a dynamic capability: Resolving the innovator's dilemma. Res. Organ. Behav. 2007, 28, 185-206. [CrossRef]

43. Lubatkin, M.H.; Simsek, Z.; Ling, Y.; Veiga, J.F. Ambidexterity and performance in small-to medium-sized firms: The pivotal role of top management team behavioral integration. J. Manag. 2006, 32, 646-672. [CrossRef]

44. March, J.G. Exploration and exploitation in organizational learning. Org. Sci. 1991, 2, 71-87. [CrossRef]

45. McNamara, P.; Baden-Fuller, C. Lessons from the Celltech case: Balancing knowledge exploration and exploitation in organizational renewal. Br. J. Manag. 1999, 10, 291-307. [CrossRef]

46. Simsek, Z.; Heavey, C.; Veiga, J.F.; Souder, D. A typology for aligning organizational ambidexterity's conceptualizations, antecedents, and outcomes. J. Manag. Stud. 2009, 46, 864-894. [CrossRef]

47. Gibson, C.B.; Birkinshaw, J. The antecedents, consequences, and mediating role of organizational ambidexterity. Acad. Manag. J. 2004, 47, 209-226.

48. Wang, C.L.; Rafiq, M. Ambidextrous organizational culture, contextual ambidexterity and new product innovation: A comparative study of UK and Chinese high-tech Firms. Br. J. Manag. 2014, 25, 58-76. [CrossRef]

49. Atuahene-Gima, K. Resolving the capability-rigidity paradox in new product innovation. J. Mark. 2005, 69, 61-83. [CrossRef]

50. Barney, J.B. Firm resources and sustained competitive advantage. J. Manag. 1991, 17, 99-120. [CrossRef]

51. Abdul Halim, H.; Ahmad, N.H.; Ramayah, T.; Hanifah, H.; Taghizadeh, S.K.; Mohamad, M.N. Towards an innovation culture: Enhancing innovative performance of Malaysian SMEs. Acad. J. Int. Stud. 2015, 4, 85-94. [CrossRef]

52. Helfat, C.E.; Peteraf, M.A. The dynamic resource-based view: Capability lifecycles. Strat. Manag. J. 2003, 24, 997-1010. [CrossRef]

53. Teece, D.J.; Pisano, G.; Shuen, A. Dynamic capabilities and strategic management. Strat. Manag. J. 1997, 18, 509-533. [CrossRef]

54. Eisenhardt, K.M.; Martin, J.A. Dynamic capabilities: What are they? Strat. Manag. J. 2000, 21, 1105-1121. [CrossRef]

55. Jurksiene, L.; Pundziene, A. The relationship between dynamic capabilities and firm competitive advantage: The mediating role of organizational ambidexterity. Eur. Bus. Rev. 2016, 28, 431-448. [CrossRef]

56. Raisch, S.; Birkinshaw, J.; Probst, G.; Tushman, M.L. Organizational ambidexterity: Balancing exploitation and exploration for sustained performance. Organ. Sci. 2009, 20, 685-695. [CrossRef]

57. Hotho, J.J.; Lyles, M.A.; Easterby-Smith, M. The mutual impact of global strategy and organizational learning: Current themes and future directions. Glob. Strat. J. 2015, 5, 85-112. [CrossRef]

58. Pedler, M.; Burgoyne, J.G. Is the learning organisation still alive? Learn. Org. 2017, 24, 119-126. [CrossRef]

59. Yung-Chul, K. Learning Orientation, dynamic capabilities and performance in Korean high-tech ventures. Adv. Manag. 2013, 6, 1-18.

60. He, X.; Huang, S.-Z.; Zhao, K.; Wu, X. The relationship between learning orientation and dynamic capability based on environmental education. EURASIA J. Math. Sci. Technol. Educ. 2018, 14, 2193-2202.

61. Ambrosini, V.; Bowman, C. What are dynamic capabilities and are they a useful construct in strategic management? Int. J. Manag. Rev. 2009, 11, 29-49. [CrossRef]

62. Fiol, C.M.; Lyles, M.A. Organizational learning. Acaad. Manag. Rev. 1985, 10, 803-813. [CrossRef]

63. Huber, G.P. Organizational learning: The contributing processes and the literatures. Org. Sci. 1991, 2, 88-115. [CrossRef]

64. Bates, R.; Khasawneh, S. Organizational learning culture, learning transfer climate and perceived innovation in Jordanian organizations. Int. J. Train. Dev. 2005, 9, 96-109. [CrossRef]

65. Crossan, M.M.; Lane, H.W.; White, R.E. An organizational learning framework: From intuition to institution. Acad. Manag. Rev. 1999, 24, 522-537. [CrossRef]

66. Zhou, K.Z.; Gao, G.Y.; Yang, Z.; Zhou, N. Developing strategic orientation in China: Antecedents and consequences of market and innovation orientations. J. Bus. Res. 2005, 58, 1049-1058. [CrossRef]

67. Mom, T.J.; Van Den Bosch, F.A.; Volberda, H.W. Understanding variation in managers' ambidexterity: Investigating direct and interaction effects of formal structural and personal coordination mechanisms. Org. Sci. 2009, 20, 812-828. [CrossRef] 
68. Ikhsan, K.; Almahendra, R.; Budiarto, T. Contextual ambidexterity in SMEs in Indonesia: A study on how it mediates organizational culture and firm performance and how market dynamism influences its role on firm performance. Int. J. Bus. Soc. 2017, 18, 369-390.

69. Peteraf, M.A. The cornerstones of competitive advantage: A resource-based view. Strat. Manag. J. 1993, 14, 179-191. [CrossRef]

70. Barney, J.B. Organizational culture: Can it be a source of sustained competitive advantage? Acad. Manag. Rev. 1986, 11, 656-665. [CrossRef]

71. Dobni, C.B. Measuring innovation culture in organizations: The development of a generalized innovation culture construct using exploratory factor analysis. Eur. J. Innov. Manag. 2008, 11, 539-559. [CrossRef]

72. Zollo, M.; Winter, S.G. Deliberate learning and the evolution of dynamic capabilities. Org. Sci. 2002, 13, 339-351. [CrossRef]

73. Hung, R.Y.Y.; Yang, B.; Lien, B.Y.-H.; McLean, G.N.; Kuo, Y.-M. Dynamic capability: Impact of process alignment and organizational learning culture on performance. J. World Bus. 2010, 45, 285-294. [CrossRef]

74. Muhammad, F.; Ikram, A.; Jafri, S.K.; Naveed, K. Product Innovations through Ambidextrous Organizational Culture with Mediating Effect of Contextual Ambidexterity: An Empirical Study of IT and Telecom Firms. J. Open Innov. Technol. Mark. Complex 2021, 7, 9. [CrossRef]

75. Cao, Q.; Gedajlovic, E.; Zhang, H. Unpacking organizational ambidexterity: Dimensions, contingencies, and synergistic effects. Org. Sci. 2009, 20, 781-796. [CrossRef]

76. Coulson-Thomas, C. Stimulating creativity, enabling innovation and supporting entrepreneurship. Manag. Serv. 2017, 2017, 26-29.

77. West, J.; Bogers, M. Open innovation: Current status and research opportunities. Innovation 2017, 19, 43-50. [CrossRef]

78. Gerhart, B. How much does national culture constrain organizational culture? Manag. Organ. Rev. 2009, 5, 241-259. [CrossRef]

79. Onkelinx, J.; Manolova, T.S.; Edelman, L.F. Human capital and SME internationalization: Empirical evidence from Belgium. Int. Small Bus. J. 2016, 34, 818-837. [CrossRef]

80. Harris, S.G. Organizational culture and individual sensemaking: A schema-based perspective. Org. Sci. 1994, 5, 309-321. [CrossRef]

81. Jahan, K.S.; Akbar, M.A. Ambidextrous culture, contextual ambidexterity and new product innovations: The role of organizational slack and environmental factors. Bus. Strategy Environ. 2019, 28, 652-663.

82. SME Corp. Malaysia, SME Survey Report 2019/20 SMEs in the New Normal: Economic Rebuilding; Secretariat to the National Entrepreneur and SME Development Council: Kuala Lumpur, Malaysia, 2021.

83. Parida, V.; Westerberg, M.; Frishammar, J. Inbound open innovation activities in high-tech SMEs: The impact on innovation performance. J. Small Bus. Manag. 2012, 50, 283-309. [CrossRef]

84. Sy, M.; O'Leary, N.; Nagraj, S.; El-Awaisi, A.; O'Carroll, V.; Xyrichis, A. Doing interprofessional research in the COVID-19 era: A discussion paper. J. Int. Care 2020, 34, 600-606. [CrossRef]

85. Tabachnick, B.G.; Fidell, L.S. Using Multivariate Statistics; Pearson Education, Inc.: Upper Saddle River, NJ, USA, 2019.

86. Hair, J.F.; Black, W.C.; Babin, B.J.; Anderson, R.E. Multivariate Data Analysis: A Global Perspective, 7th ed.; Pearson Education Inc.: Upper Saddle River, NJ, USA, 2010.

87. Cavana, R.; Delahaye, B.; Sekeran, U. Applied Business Research: Qualitative and Quantitative Methods; John Wiley \& Sons: Hoboken, NJ, USA, 2001.

88. Bhattacherjee, A. Social Science Research: Principles, Methods, and Practices, 2nd ed.; Creative Commons Attribution: Zurich, Switzerland, 2012.

89. Podsakoff, P.M.; MacKenzie, S.B.; Lee, J.-Y.; Podsakoff, N.P. Common method biases in behavioral research: A critical review of the literature and recommended remedies. J. Appl. Psychol. 2003, 88, 879-903. [CrossRef]

90. MacKenzie, S.B.; Podsakoff, P.M. Common Method Bias in Marketing: Causes, Mechanisms, and Procedural Remedies. J. Retail 2012, 88, 542-555. [CrossRef]

91. Gaskin, J. Confirmatory Factor Analysis Gaskination's StatWiki. 2012. Available online: http://statwiki.gaskination.com/index. php?title=Main_Page (accessed on 20 June 2021).

92. Garson, G.D. Structural Equation Modeling; Statistical Associates Publishing: Asheboro, NC, USA, 2012 ; p. 237.

93. Anderson, J.C.; Gerbing, D.W. Structural equation modeling in practice: A review and recommended two-step approach. Psychol. Bull. 1988, 103, 411-423. [CrossRef]

94. Bentler, P.M.; Bonett, D.G. Significance tests and goodness of fit in the analysis of covariance structures. Psychol. Bull. 1980, 88 , 588-606. [CrossRef]

95. Byrne, B.M. Structural Equation Modeling with AMOS: Basic Concepts, Applications, and Programming, 2nd ed.; Taylor and Francis Group: New York, NY, USA, 2010.

96. Chiu, C.-M.; Wang, E.T.G. Understanding Web-based learning continuance intention: The role of subjective task value. Inf. Manag. 2008, 45, 194-201. [CrossRef]

97. Lyytinen, K.; Gaskin, J. Mediation and Multi-Group Analyses. 2011. Available online: http://www.kolobkreations.com/ Mediation\%20and\%20Multi-group\%20Moderation.pptx (accessed on 2 May 2021).

98. Raisch, S.; Birkinshaw, J. Organizational ambidexterity: Antecedents, outcomes, and moderators. J. Manag. 2008, 34, 375-409. [CrossRef]

99. Gupta, G.; Bose, I. Strategic learning for digital market pioneering: Examining the transformation of Wishberry's crowdfunding model. Technol. Forecast. Soc. Change 2018, 146, 865-876. [CrossRef] 